\title{
The Foreign Influences on Royal Statuary During the Kushite Period "25th Dynasty
}

\author{
Sherif Saied El Sabban ${ }^{a}$ \\ Marwa El-Sayed Moustafa ${ }^{c}$, \\ ${ }^{a}$ Prof. of Egyptology, Faculty of Tourism and Hotels, Minia University \\ ${ }^{\mathrm{b}}$ Assistant Prof. of Egyptology, Faculty of Tourism and Hotels, Minia University \\ ${ }^{\mathrm{c}}$ Ph.D Researcher, Faculty of Tourism and Hotels, Minia University
}

\section{Keywords}

Foreign Influences

Twenty Fifth Dynasty

Kushite Period

Kushite Kings

Royal Statuary.

\begin{abstract}
The aim of this study is to trace the difference between the Royal Egyptian art and the foreign, on the other hand, revealing the powers which affected the artistic changes that contributed in the progress of artistic works in that period, because the foreign influence during that period is one of the important aspects which largely affected the Egyptian civilization in general and the Egyptian arts in particular. Thus, to achieve the aims of the study, it was followed the descriptive historical method of scientific research which deals with studying the subject, maKing comparisons, detecting similarities and differences, describing the pieces scientifically and studying the connections between them to find out the artistic bases of those influences.
\end{abstract}

Printed ISSN $2357-0652 \quad$ Online ISSN 2735-4741 


\section{Introduction}

The Egyptian Sudanese relationship dates back to an early history as many of the monuments found in Egypt during the predynastic age had contemporary counterparts in Sudan, even the civilization aspects in both countries were almost similar during the same period, the southern residents immigrated into Egypt since the earliest times but those immigrations remarkably increased during the time of the New Kingdom when Nubia has become an integral part of Egypt $^{(i)}$.

The Twenty-Fifth Dynasty controlled Ancient Egypt from (744-656 BC). The Kushite Dynasty which managed to invade Egypt and stabilize its control in the country started with King "Alra". In spite of the great importance given in the sources to that King after the end of his reign, he is not considered as the real founder of the new dynasty, but the real founder of the twenty-fifth Dynasty in Egypt is King " Piankhi " (ii).

"Shabatka" was the second King of the Twenty-fifth Dynasty of Egypt who ruled from $714 \mathrm{BC}-705 \mathrm{BC}$, according to the most recent academic research. He was a son of "Piankhi", the founder of this dynasty (iii). Among his most important monuments is his shrine in Karnak temple which was built near the sacred Lake.

"Shabaka" succeeded his uncle "Shebitku" on the throne, Shabaka's reign is significant because he consolidated the Nubian Kingdom's control over all of Egypt from Nubia down to the Delta region. It also saw an enormous amount of building work undertaken throughout Egypt, especially at the city of Thebes, which he made the capital of his Kingdom (iv). In Karnak he erected a pink granite statue of himself wearing the double crowns of Egypt ${ }^{(v)}$.

Taharqa's reign can be dated from $690 \mathrm{BC}$ to $664 \mathrm{BC}$. He was the son of "Piankhi", "Taharqa" was perhaps the greatest ruler of the 25th Dynasty and is certainly the best documented. He re-established the Upper Egyptian city of Thebes as a major religious center, restoring its many great temples and the power of the priests as an intellectual, spiritual and political force within Egypt ${ }^{(v)}$.

"Tantamani" took the throne after the death of King "Taharqa". In his reign, Egypt faced the third Assyrian invasion which was lead by King "Ashurbanipal" who controlled Delta so that King fled to to Napata .

Psamtik II, the third ruler of the following dynasty, the Twenty-Sixth Dynasty, deliberately destroyed monuments belonging to the 25th Dynasty of Kushite Kings in Egypt, erasing their names and their emblems of royalty from statues and reliefs in Egypt ${ }^{\text {(vii). }}$ 
But the coming of the 25th Dynasty from Kush is a unique event in the Egyptian history, as their reign was parallel to a new era during which the Egyptian art was active especially sculpture, therefore the Kushite Kings quickly and intelligently made some changes, as they reused the old Egyptian ways of representing the King in an ideal shape, and in the same time they represented the body features that distinguished their race, So by this way they mixed between the Kushite and Egyptian elements in a way that made Egyptians accept them and also enabled the Kushites to rule the country.

Moreover, those Kings were never depicted in Egypt as foreigners. The foreigners who were previously depicted in the Egyptian art were limited to servile enemies and slavish tribute payers. Therefore, solving this problem with the least amount of mistaKing depended firstly on the skills of craftsmen and artists (viii). So, the arts of that period gathered between the Egyptian character in its different eras and the development brought by the Kushite art, which achieved a kind of wonderful balance between development, and simulation.

The Egyptian art during the Kushite period is considered one of the important things that expressed the renewable vitality of the Egyptian art in the end of the 8th century and the start of the 7th century BC. But it disappeared by the end of the 25th Dynasty and only a little of its Style left in some examples of the later dynasties; though it was modified it disappeared completely and quickly.

Although the Twenty-Fifth Dynasty controlled Ancient Egypt for only 88 years, it holds an important place in Egyptian history due to the restoration of traditional Egyptian values, culture, art, and architecture.

The following topics shall display the most important foreign influences that appeared on the Royal statuary during the Kushite dynasty and showing the new artistic spirit which influenced the community because of integration with the incoming culture, as well as these influences clearly appearing in crowns, clothing, ornaments, facial and anatomical characteristics.

\section{Kushite Characteristics}

\subsection{Royal Crowns}

Crowns and Headdresses worn by Kushite Kings in Egypt were various. Though most of which belong to an Egyptian origin (ix), new artistic elements were added to distinguish them from the 
traditional Egyptian crowns, therefore, they were exclusively related to the Kushite Kings.

They were also distinguished with the prominent head cover which was known as the "Kushite Beret". This Cap, apparently, replaced the Egyptian blue crown. All the Egyptian traditional crowns were obviously worn by the Kushite Kings except the blue crown, which hasn't been seen in any Kushite inscription or statue, moreover, the Egyptian Gods never wore it (x), which contradicts with the desire of the Kushite Kings to care for the religious elements that supports their presence in Egypt and the throne. There may be another deeper reason, that is, the Kushite Kings related the blue crown to their enemies in the Delta ${ }^{\left(x^{x}\right)}$.

Anyway, the "Kushite Beret" was considered as an alternative to the blue crown and it is a symbol, it replaced the white crown of Upper Egypt, as God Amun appeared on the stela of "Piankhi" while giving to the King the double crown which consisted of the red crown of lower Egypt and the "Kushite Beret" (Fig. 1). The Cap also appeared on the statues of Kushite Kings as a tight cap over the head hanging down over the forehead with round laces in front of the ear, the material of which the cap is made is unknown. It looked like the blue Egyptian crown.

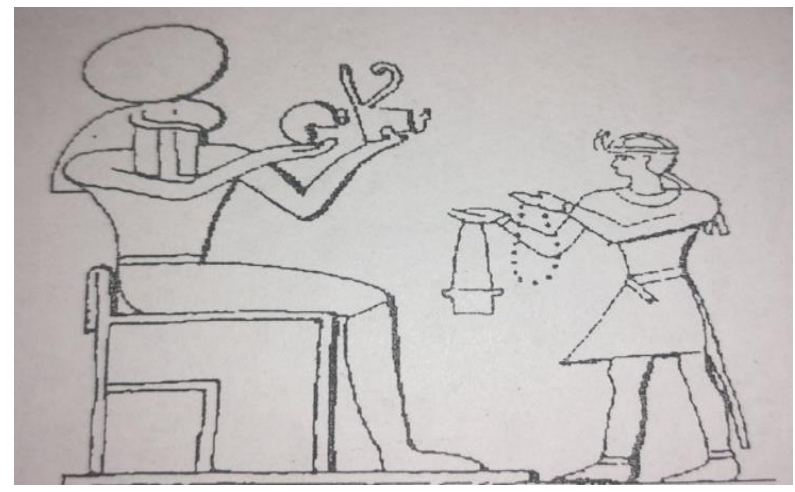

(Fig. 1), Stela of "Piankhi".

After:, Török, L., The royal crowns of Kush : a study in Middle Nile Valley regalia and iconography in the 1st millennia B.C. and A.D., (Oxford 1987), no. 1 .

It was covered with dots or dotted circles, those circles might express the metallic ornaments of the cap (Figs. 2 a, b) (xii). It was previously thought that the circles represented the short curly hair and that the head cover is just a crown to be worn on the bare head, 
and sometimes two wings of a falcon were depicted on the two backsides of the head beside the ear (Figs. 3a, b) (xiii).

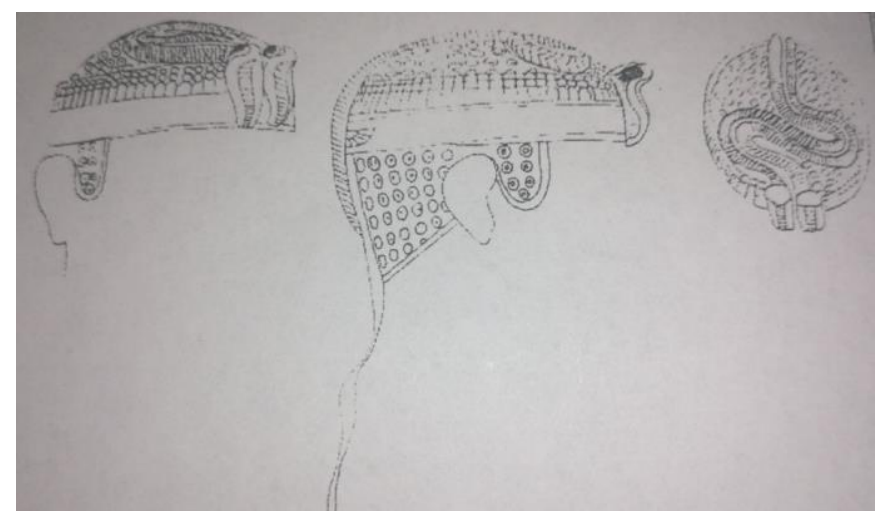

(Fig. 2a), The "Kushite Beret"

After: Török, L., The royal crowns of Kush : a study in Middle Nile Valley regalia and iconography in the 1st millennia B.C. and A.D., (Oxford 1987), no.2.
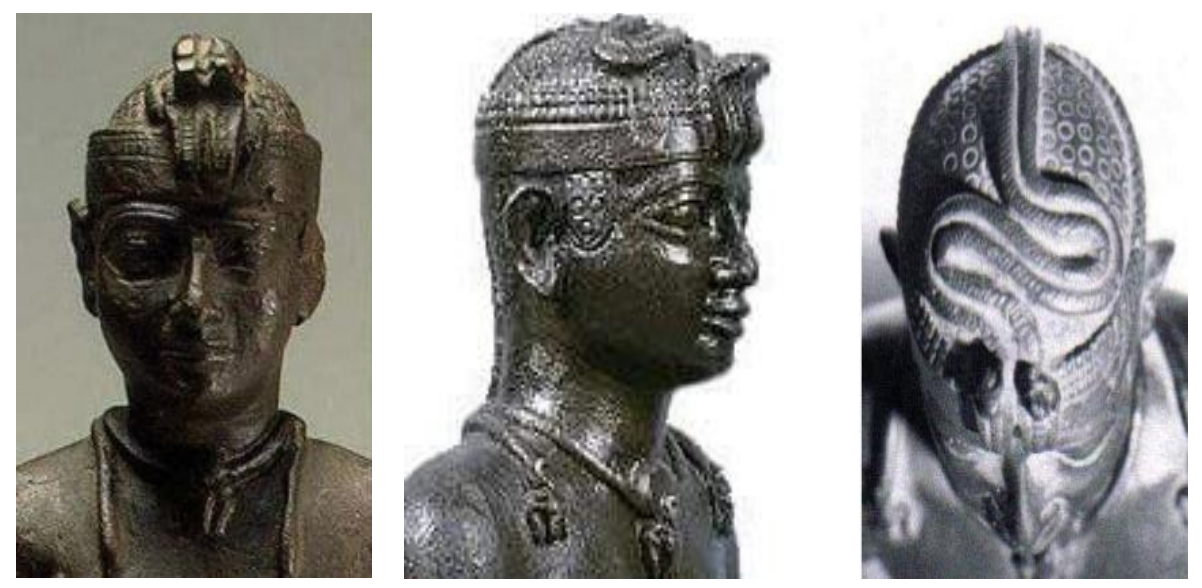

(Fig. 2b), Statue of King "Shabaka", with Kushite Beret. Athens Museum. After: Hill, M., Royal Bronze Statuary from Ancient Egypt: with Special Attention to the Kneeling Pose, (Leiden 2004), pl. 29, k-1, cat. 17. 


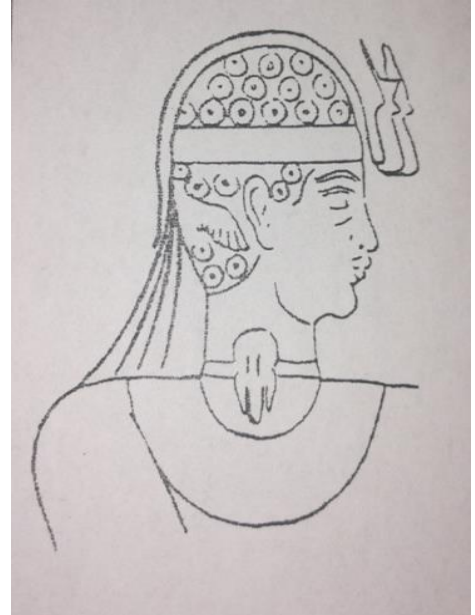

(Fig. 3a), The depiction of two wings of a falcon

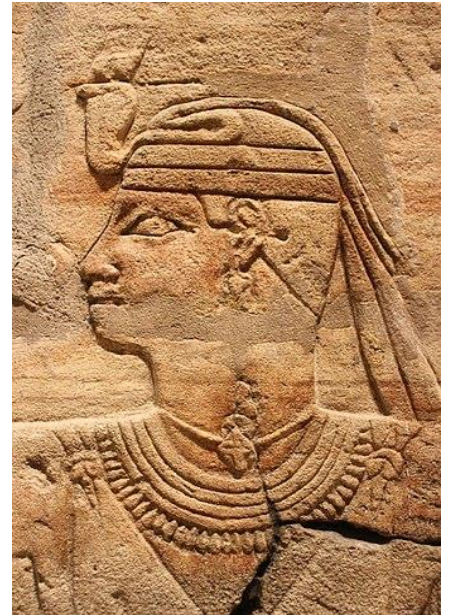

(Fig. 3b), Pharaoh Taharqa of Ancient Egypt's

on the two backsides of the head. 25th Dynasty. Ashmolean Museum, After: Schäfer, H. Von., Eine Bronzefigure des Taharka,

After: https://www.wikiwand.com/en/Twenty ZÄS33 (1895), p. 115. Fifth Dynasty_of_Egypt.

Russmann tried to relate the Kushite Cap to Egyptian Origins depending on tight similar Caps found on the Egyptian inscriptions and statues, but the used example, though they looked tight like the Kushite Cap, are different in other details. The nearest example is the Cap which is depicted over the head of King "Iuput II"

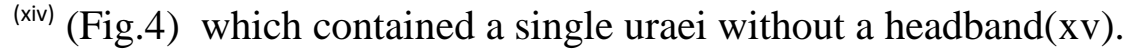

On this basis, it is considered the only Kushite royal head cover that came to Egypt, the shape appeared in the pictures of the Kings belonging to the 25th Dynasty, by the falling of that Dynasty, it disappeared from the Egyptian royal signs and was never used again; this is the best clue that proves its foreign origin as it appeared and disappeared suddenly. However, it remained in use among the Kings of Sudan. The appearance of the Kushite Cap in many statues and inscriptions of the 25th Dynasty undoubtedly aimed to assert their Nubian origin. 

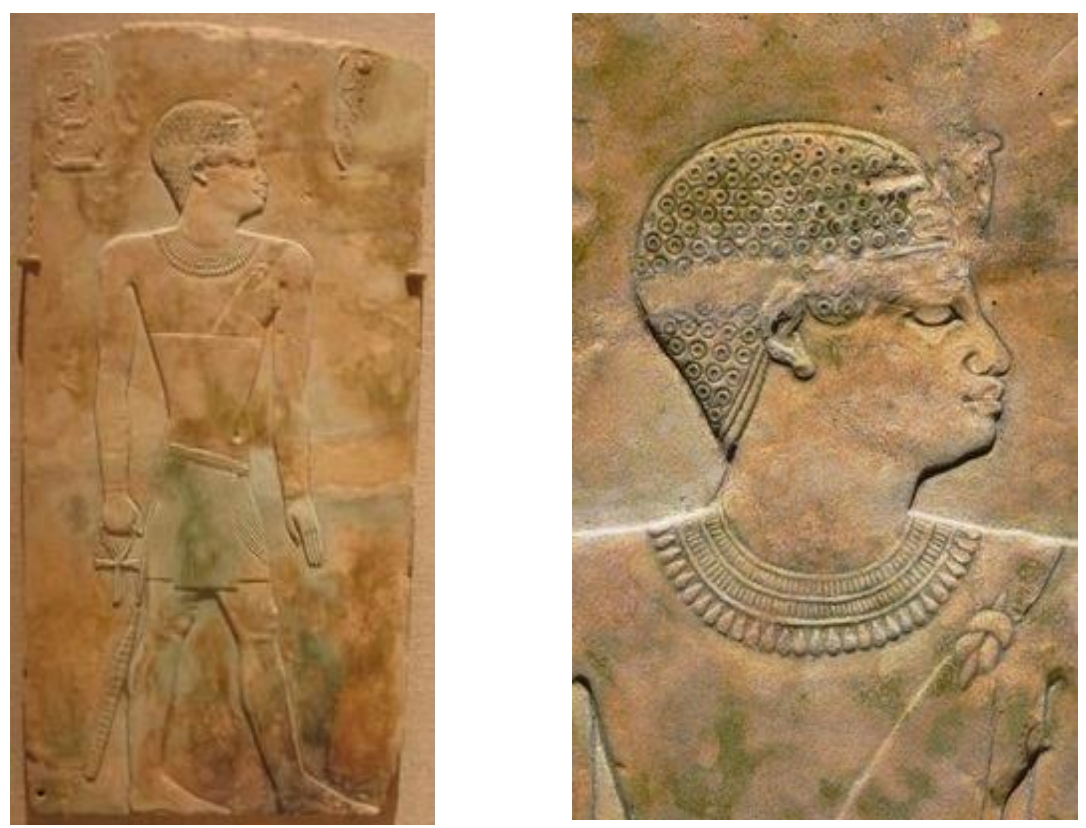

(Fig.4), Relief of King "Iuput II", 23rd dynasty.It kept in Brooklyn Museum, no. (59.17).It is 29.3 high, 15.9 width. Made of Polished Green Faience.

After: https://www.brooklynMuseum.org/opencollection/objects/3669.

The Kings of that Dynasty wore, other than the "Kushite Beret", all the traditional Egyptian crowns except the blue one, in spite of this, some additions attributed to the Kushite Kings were applied to those crowns; the white crown of Upper Egypt and the red one of Lower Egypt were noticed to have a tongue sticKing out of the cheek in the lower part of the ear, the start of the tongue was always round leaving an empty space between it and the short moustache adjacent to the lower part of the ear. Sometimes the tongue and the short moustache were weaved together with a vertical tape used as a tool to fix the Crown on the head when the King was depicted wearing his false beard. This tape extended down to the beard all along the cheekbone so it connected the beard to the crown (Fig.5a); this feature almost existed in all the inscriptions of "Shabaka" which depicted him in the Egyptian crowns ${ }^{\text {(xvi) }}$ (Fig.5b). 

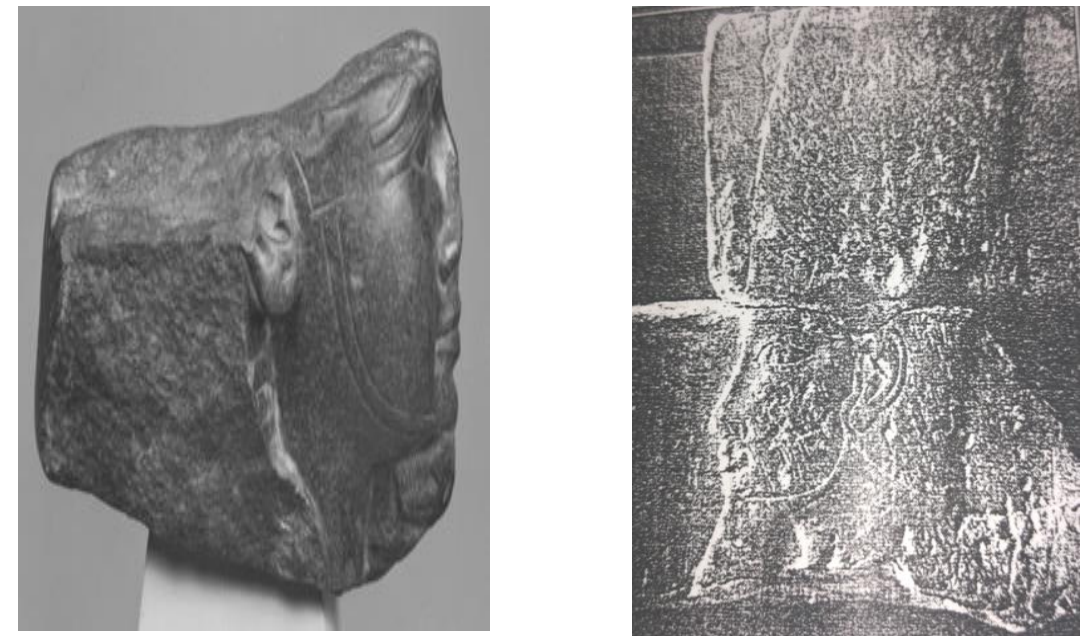

(Fig.5a), Sphinx Face of Kushite King with a crown (Fig.5b), Stela of King "Shabaka" with a crown which has a tongue attached to the beard. Brooklyn Museum, has a tongue attached to the beard. 25th dynasty.

After: Russman, E., Two Royal Heads of the Late Period After: Mysliwiec, K., Royal Portraiture of the in Brooklyn, BMA X, (1968-69), fig. 15. Dynasties XXI- XXX, (1989), pl. XXXIb.

Besides the Three Crowns, the white, red and the double, the Kushite Kings wore the traditional head covers "Nemes" (Fig. 6), the complex crowns and the "Khat" wig. They all had one special feature that is the double uraeus which consisted of two cobras on the forehead. Because this uraeus was the feature that distinguished all the crowns worn by Kushites which was called the "dual Kushite uraeus" (xvii). 


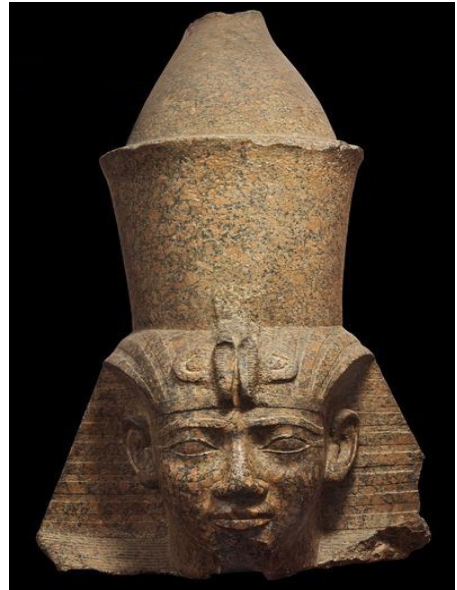

(Fig.6a), Colossal head of King "Shabaka".

Egyptian Museum After:

https://en.wikipedia.org/wiki/Shab aka/

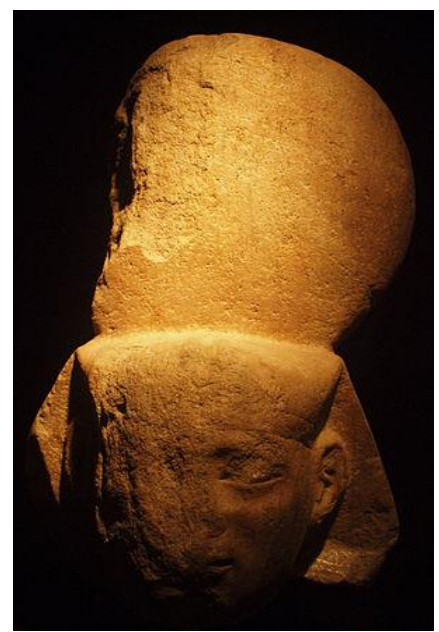

(Fig.6c), Head of King "Shabaka", Munich Museum

After:https://www.wikiwand.com/en/S habaka

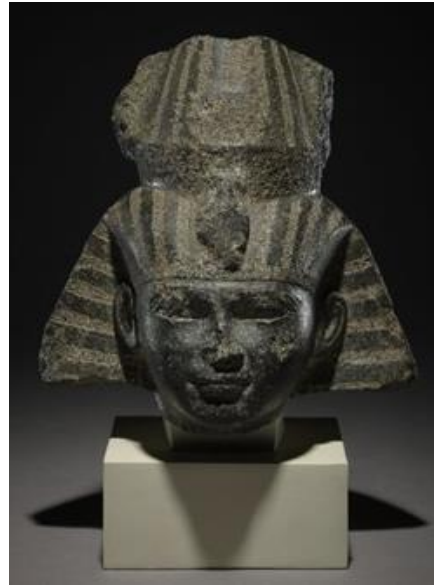

(Fig.6b), Granite head of a Kushite British Museum After:

https://www.britishMuseum.org/coll ection

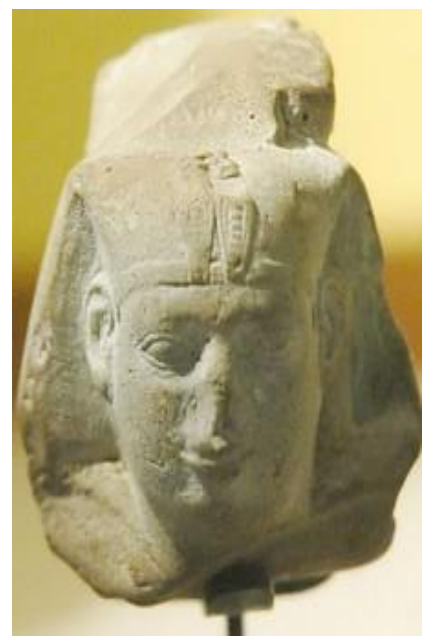

(Fig.6d), Head of King "Shabaka", Louvre After:

https://mathstat.slu.edu/ bart/Shab aka

(Fig.6), Kushite Kings wear "Nemes Headdress" and Various Crowns with double uraeus on the forehead. 
Though the Cobra has an Egyptian origin, depicting it in a dual shape was rare among the Egyptian Kings while Queen "Ti" of the 18th Dynasty was depicted with a double uraeus over her forehead (Fig. 7). The cobras are crowned; the proper right cobra wears the Hedjet crown of Upper Egypt, while the proper left one wears the Deshret crown of Lower Egypt. This may agree with the opinion saying that this queen belonged to a Nubian origin.

On the contrary, no remains were found depicting the Queens of the 25th Dynasty with the dual uraeus, while an example of a triple uraeus worn by a queen or a goddess was found and dated back to the 25th Dynasty (xviii). The oldest Egyptian example of wearing the dual uraeus was the God "Mento" of the middle Kingdom which also appeared in the same shape during the time of the 25th Dynasty in a stela depicting him hugging the King "Tantamani" in Karnak ${ }^{(x i x)}$.

The more distinguished feature in depicting the dual uraeus during the Kushite age was the existence of two cobras crowned with the double crowns of upper and lower Egypt, the white and red ones. The only Egyptian example that depicted the dual snake crowned with the double crowns was the head of Queen "Ti" in the Egyptian Museum. The left cobra usually appeared with the white crown and the right cobra crowned by the red one. One of the features that distinguished the uraeus during the Kushite time was its presence on the forehead not on the crown.

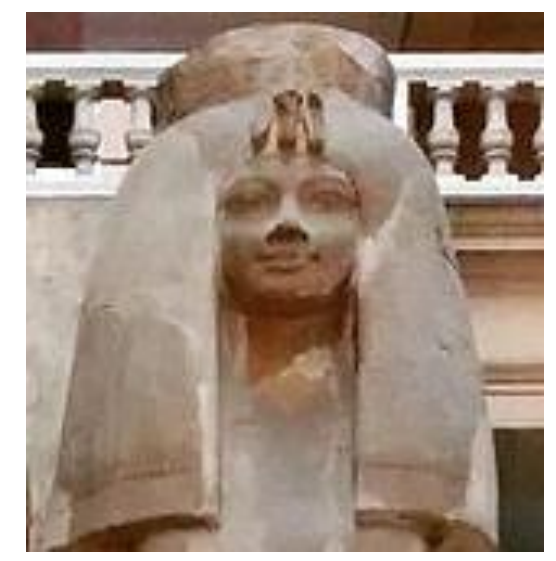

(Fig. 7), Details of Ti's Crown from the Monumental Statue of Queen" Ti" 18th dynasty,

After: Egyptian Museum, no. (FB84JT). Limestone.

https://en.wikipedia.org/wiki/Colossal_statue_of_Amenhotep_III_and Tive. 
It is well-known that the two cobras were related to the goddesses "Nekhbet" and "Wdjet" since the beginning of the Egyptian civilization, they are the protecting Gods of upper and lower Egypt. The appearance of God "Mento" with the dual ureaus and the existence of a sign that "Wesir" also appeared with it (xx), all these assert the Kushite thinKing and searching for a religious motive to reinforce their rule in the country and to justify taKing over the authority.

There is another example of Crowns worn by Kushite Kings in Egypt which was strange in shape, yet distinguished. It was never depicted on the inscriptions of Karnak but existed on the granite head of King "Tahraqa" in Nubian Museum (Fig. 8). Though only the Cap remained of the crown but its existence is clear above it; it normally consisted of four long adjacent feathers on a cylindrical base connected to the semi spherical Cap, below this formation there is another Cap maybe with the aim to cover the head under this enormous weight which is very high in the same time and which may be partially made of a metal. All this is accompanied by the always existent dual ureaus with the two crowned cobras ${ }^{(\times x)}$.

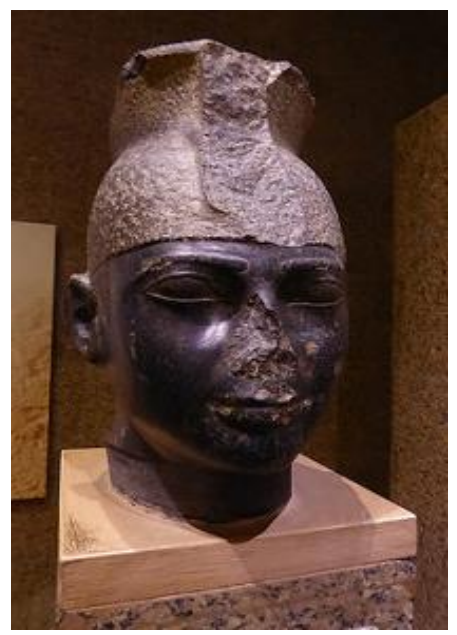

(Fig. 8), Head of King "Taharqa" wears a crown with remains of four long adjacent feathers. Nubian Museum. After: https://www.pinterest.com/pin/310255861805543014/

This form of Crowns has no resemblance among the Egyptian crowns; the Remains of the 25th Dynasty prove that the Crown is dated to this Dynasty. No trace of this crown was found among the reliefs of Kushite Kings in karnak, the same applies to the statues except that statue of "Taharqa" in the Nubian Museum. This crown 
appears so much in the reliefs of the successors of the Kushite Dynasty in "Nabta" and "Meroe" where it turned out to be the head cover of God "Anhur-Shu" (Fig. 9), so it is suggested that there was a sect among the Kushites for worshipping this God.

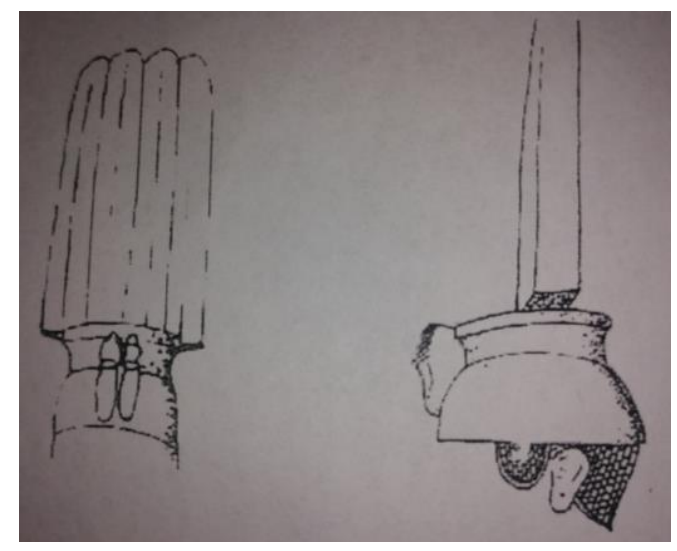

(Fig. 9), The Royal Kushite Crown of God "Anhur-Shu".

After: Török, L., The royal crowns of Kush, (1987), nos. 78, 80.

The last model of crowns appeared on the Kushite Kings was the shape of the Sun disc over the Royal head cover " Nemes" with the dual ureaus over the forehead which all are Egyptian elements (Figs. 6 b, c, d).

\subsection{Clothes}

The clothes of Kushite Kings are in general Egyptian traditionaly which depended on the clothes of the New Kingdom and the kilt inspired from the Old Kingdom. The only remarkable wear was the one whch appeared in reliefs of Karnak on King "Tantamany" (Fig. 10), and King "Taharqa" in "Kawa" (xxii) which represents two falcons with crisscrossed wings on the King's chest for protection. This design can only be considered as a pectoral or a very old coat as some think that it firstly appeared on the Kushite Kings but some others think that it dates back to the 6th Egyptian Dynasty or maybe older ${ }^{\text {(xxiii) }}$. 


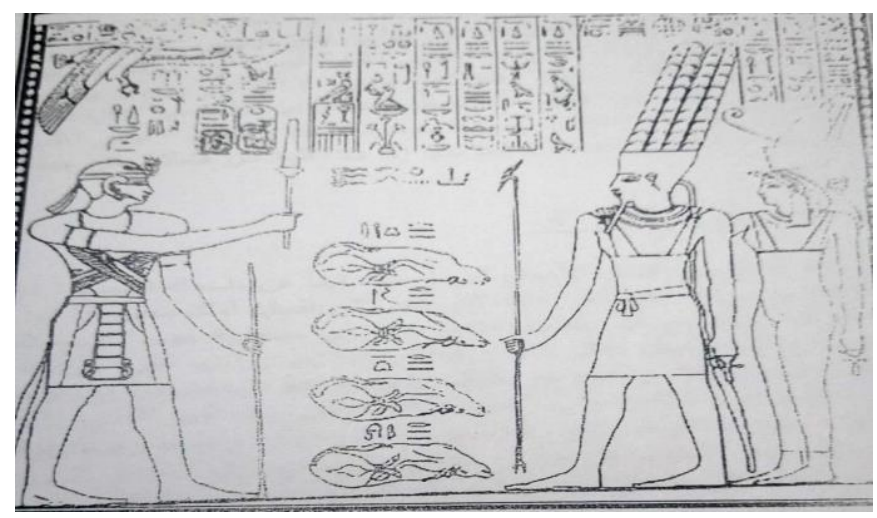

(Fig. 10), Temple Relief of King "Tantamani" with gods "Amun" and "Mut", 25th dynasty, Karnak Temple. After: Leclant, J., Rechershes, (1965), pl.

\subsection{Ornaments}

\section{LXIX, b..}

Most necklaces and bracelets appeared on the Kushite Kings were ram-shaped; this is an absolute expression of intense devotion for worshipping and serving the ram-headed God "Amun". In spite of the Egyptian origin of the elements which formed the Kushite ornaments, they had a new shape which was never known by Egyptian Kings before.

- The Ram's Head Amulet created by Kushite Kings distinguished them even more than the dual uraeus as it wasn't known before and at first it was used only by the Kings of this Dynasty. It existed in most bronze and Stone statues and the reliefs of Karnak This amulet looked like a ram's head with two crooked hooked horns centered in the side, the forehead is decorated with a dual uraeus with two cobras crowned by the red and white crowns, it sometimes appeared with a single uraea, there is always a Sun Disk over the Ram's Head (Fig. 11) (xxiv). This amulet was used as a necklace, in such a case the amulet was hanged by a firmly tied rope around the neck with its two parts hanging over the shoulder with a ram's Head in the end of each (Fig. 12). In case it is used as an ornament for the ear, it hangs from an earring that looks like a small disk. 


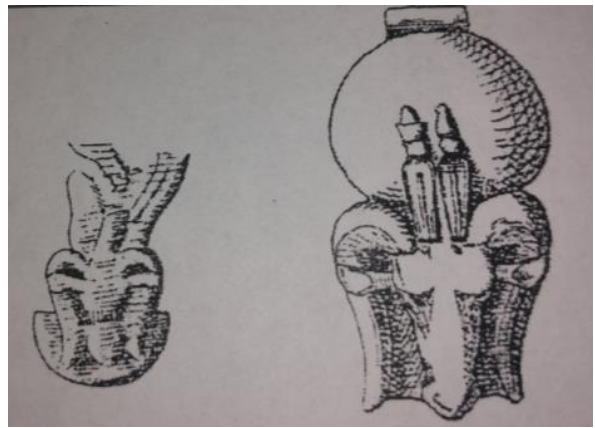

(Fig. 11), The Ram's head amulet. After: Schäfer, H. Von., ZÄS 33 (1895), p. 114.

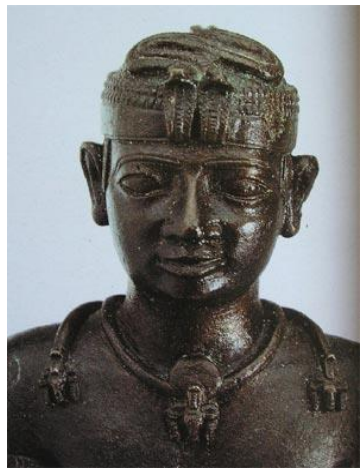

(Fig. 12a) King "Shabaka" amulet, Athens Museum

After: https://egiptologia.com/bronceantiguo-egipto/

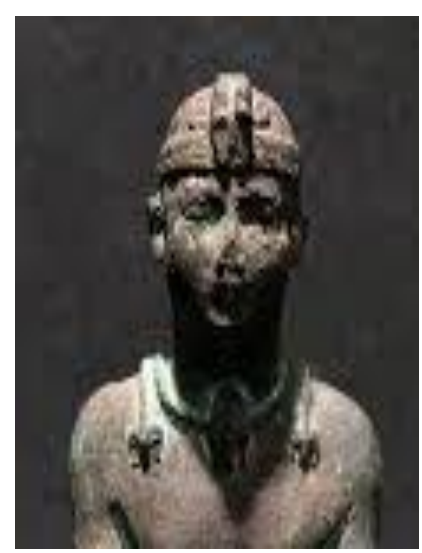

(Fig. 12c) King "Taharqa" amulet, Copenhagen Museum

After: https://egiptologia.com/bronceantiguo-egipto/

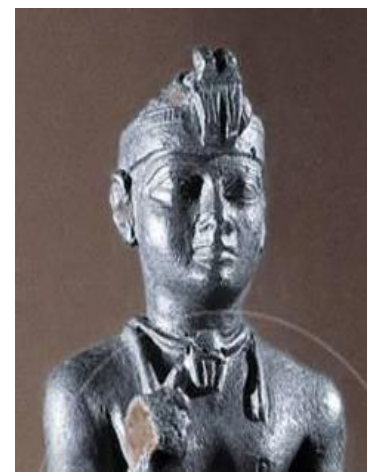

(Fig. 12b) Statuette of kushit Ruler, Hermitage

After:

https://www.allposters.com/Ancient

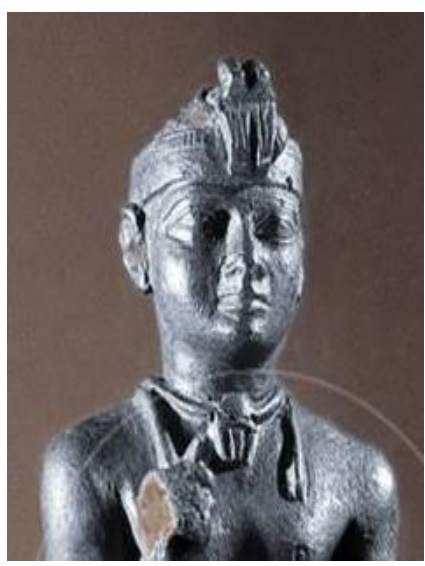

(Fig. 12b) Statuette of kushit Ruler, Hermitage

After:

https://www.allposters.com/Ancient

(Fig. 12), Kushite Kings wear various models of The Ram's head amulet. 
- Earrings were few in the royal statues and reliefs of this Dynasty. They also appeared in a ram's head shape, in some reliefs of "Shebitku" in Karnak the King was depicted wearing an earring but in a simple round shape or the shape of an earring which is represented in Karnak reliefs of "Tantamany" (Fig. 10).

- Bracelets The depiction of bracelets of the arms and wrists was rare but they appeared in some statues like the bronze statue of "Shabaka" in Athens Museum (Fig. 13) and also in Isna reliefs of King "Shabaka" (Fig. 15).

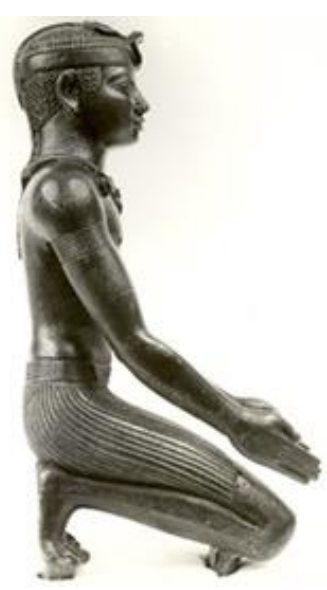

(Fig. 13), The bracelet of the arm and wrist in the Bronze Statue of King "Shabaka", Athens Museum.

After: Bianchi, R. S., Cleopatra's Egypt: Age of the Ptolemies, (Brooklyn 1988, fig. 31.

In the reliefs King "Tantamani" appeared wearing an arm bracelet (Fig. 10). The rarity of wearing earrings and bracelets in the inscriptions and statues of Kushite Kings in Egypt is due to the King's ignorance, which may be deliberate because it may show a barbarian taste. Some of the ornaments created by the Kings of this Dynasty the Ram's crooked horn centered around the ear with an earring hanging from the ear over that horn.

\section{Anatomical Characteristics of Kushite Kings Statues}

There are many characteristics in the statues of the 25th Dynasty that are considered as signs, which cannot be ignored 
referring to their Nubian origin and distinguishing them from others. Though they resembled Egyptians in clothes and some crowns, they, undoubtedly, were distinguished from Egyptians with facial and anatomical characteristics.

- The Head always appeared round, that's why the "Kushite Beret" used to focus on the round shape of the head.

- Eyes did not have a fixed shape; they sometimes were middlesized in most of thr statues of King "Shabaka" (Fig. 6a, c, d) $\&$ (Fig. 8), and wider in some of the statues of King "Taharqa" (Fig. 12a) while they were almond-shaped and wider in the statues of King "Shebitku" (Fig. 14).

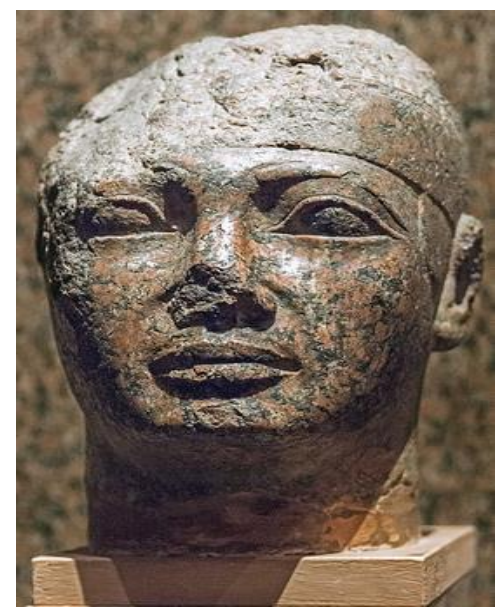

(Fig. 14), The pink Granite Head of King "Shebitku", Nubian Museum. After: https://en.wikipedia.org/wiki/Shebitku

- Eyebrows mostly looked horizontal and straight above the nose, in case there is a cosmetic line on the eye; the eyebrow is parallel to it (Fig. 14).

- The Forehead is wide and sliding upwards. The nose was mostly depicted short with wide holes so that it looks wide in general.

- Kushite Fold All the pictures of Kushite Kings commonly have a wrinkle on the cheek extending from above the nostrils. Though it is a basic characteristic, this wrinkle, which is known as "The Kushite fold" (xxv), had several different forms. Ranging from just hinting of the presence of a thin fleshy fold next to the nostrils as in many statues and reliefs of "Taharqa", to an extra big curve as in the reliefs of " Shebitku " and his granite head in Nubian Museum (Fig. 14) 
where the fold is shaped like the letter (S). This characteristic was noticed to be depicted in the Egyptian art since its start but it was used for the depiction of Nubians. Below the eye, a low part formed with the fold, which makes full and prominent cheeks, so the general look of the face inspired to fullness.

- The mouth in most of the Royal pictures the mouth looked small and horizontal, but because of the full lips the mouth looked wide and a little prominent, the lower lip used to be bent up while the upper lip sometimes was bent up and some other times looked horizontal, in both cases the mouth looked bent up with the existence of a deep hole at the corners of the mouth.

- The chin the short round chin forms with the bones of the jaws a wide cheek area, and it mostly goes down towards the neck. This form appeared clearly in the statues of "Shebitku " and "Taharqa".

- The neck looked short and thick except in the reliefs of " Shabaka " in "Isna" (Fig.15) where the neck looked extremely long which wasn't common the depiction of the Kushite Kings, though, it was depicted thick.

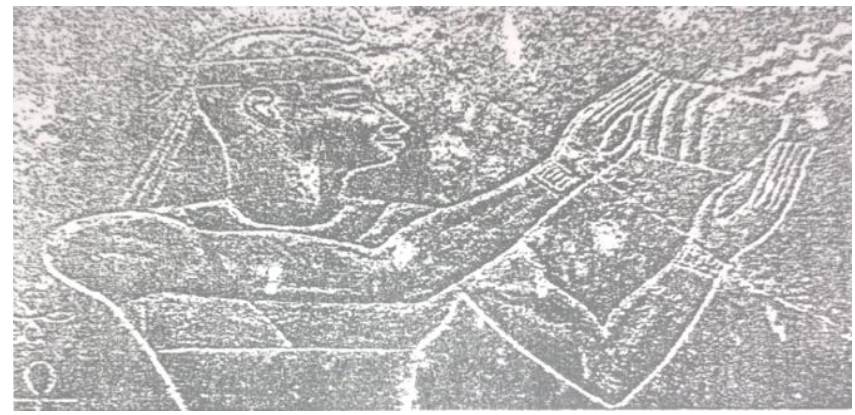

(Fig. 15), Reliefs of King "Shabaka " on "Isna" Naos, Egyptian Museum, After: Mysliwiec, K., Royal Portraiture, (1988), pl. XXXIIb.

- The body shape Shoulders looked wide, and the navel is specified with a circle from which a straight thread separates the abdomen into two parts going up to the chest which is known as the dual division of the torso (Fig.16 a, b), the anatomical characteristics of the body muscles especially the legs were always focused on, the muscles were depicted through depicted parallel shallow grooves starting from down the knee until the ankle on both sides of the leg (Fig. 17). 


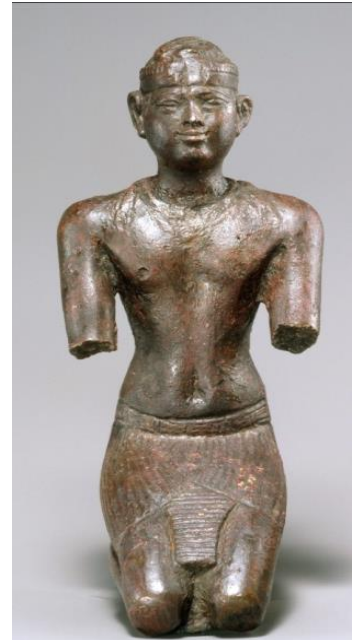

(Fig. 16a), Statuette of unknown Kushite pharaoh Metropolitan Museum After:

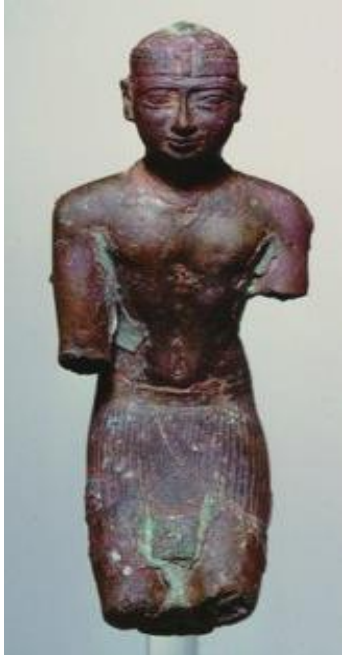

(Fig. 16b), Statuette of Taharqa.

Brooklyn Museum After:

https://www.metMuseum.org/toah/ht/04 https://www.brooklynMuseum.org/obje lafe.htm cts/3780

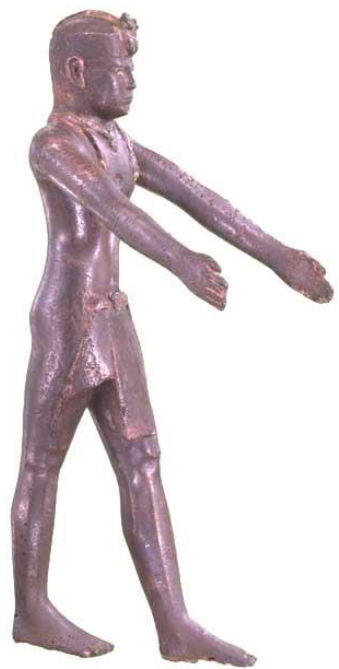

(Fig. 17), Statue of unknown Kushite King, Chicago Museum. After: https://oi.uchicago.edu/Museum-exhibits/nubia/Kushite-Kingdom

Eventually, we should mention to the important role played by the Kushite Kings so as to be accepted by Egyptians as their governors, Despite the obvious foreign influence on the statues, the 
same statues bears the Egyptian artistic characteristics, which confirm the Kushite Kings intelligent that they fastly could make some changes that were mixed with the Egyptian elements in a way that can be accepted by the Egyptians and in the same time enforced the Kushite control over the country, and those Egyptian features can be summarized as follows:-

- Those foreigners always tried to adopt the Egyptian religious customs. Everything not related to the Egyptian religion was not important for them like "the blue crown" as an example. It was noted that the goddess "Isis" was very popular at the time, so the King started depicting himself in the shape of a child god among the Trinity in every local area (xxvi). He also tended to depict himself while being breastfed by one of the goddesses especially "Isis".

- They used all the crowns and slogans related to the Egyptian Gods. They wore white, red and the double crowns, the Kushite Kings wore the traditional head covers "Nemes", the complex crowns and the "Khat" wig (Fig. 6).

- Sticking to the old positions of statues which were known since the Old Kingdom was one of the civilization artistic features of that time such as the traditional pose with the left leg forward (Fig. 17), the King's kneeling statues (Figs. 13, 16) .

- Clothes are the most artistic feature to be influenced by the Egyptian culture, that the pure Egyptian style didn't vanish as a result of the new influences, it remained in a number of statues. We found many statues wear (Shendyt kilt), with a belt (Figs. 13, 16, 17). This shows the commitment of the Kushite to the inherited traditions of the grandfathers to keep balance between the new influences over the Egyptian civilization and the long-timed inherited customs .

\section{Conclusion}

The art of Ancient Egypt mostly related to its policy, it was also affected by the periods of invasion, though the Egyptian culture along its history followed some fixed artistic bases and traditions, this did not prevent the foreign influences. Egypt adopted some foreign artistic ideas and inventions during its growth stages and during the utmost of its flourish and greatness. All the foreign artistic imports always confirmed the greatness of Egypt and its political, literary and artistic sovereignty over those countries, this is due to the authenticity of the Egyptian Ancient civilization, which could absorb all those 
strange artistic elements and could form them and present them in an innovative style.

The Ancient Egyptian art succeeded very much during the Kushite period on combining, in the same time, between the old traditions of the Egyptian art and showing the new artistic spirit, which influenced the community because of the integration with the coming culture.

A new artistic style appeared which was collected between the idealism of the Old Kingdom and the realism of the middle Kingdom and also many arts of the new Memphite style which was characterized with reviving the Ancient Egyptian art along its different times in terms of cloths, crowns and ornaments.

The Egyptian community realized the importance of its predecessors' cultural heritage so that the coming culture could not make it abandon its Ancient traditions, whether artistic or religious. Though Kushite Kings made a remarkable prosperity in the Egyptian art, the artistic styles disappeared by the fall of the 25 th Dynasty as only few of these styles remained in some artistic examples during the following dynasties. So, the Ancient Egyptian art has proven that it can be a distinct and enduring art, influenced other arts surrounding it in the Ancient world more than influenced by it.

Finally, we can say that the Kushite statues had in common a number of characteristics that can be considered as signs, which cannot be ignored. These characteristics clearly refer to their Nubian origin and distinguish them. They, in addition to clothes, crowns , ornaments and tools, form the total counted Kushite Influences on the Egyptian sculpture .

\section{List of Figures}

(Fig. 1): Stela of "Piankhi".

(Fig. 2a): Model of the "Kushite Beret".

(Fig. 2b): Statue of King "Shabaka”, with Kushite Beret.

(Fig. 3a): Model of the depiction of two wings of a falcon.

(Fig. 3b): Reliefs of King Taharqa.

(Fig. 4): Relief of King "Iuput II".

(Fig. 5a): Sphinx Face of Kushite King.

(Fig. 5b): Stela of King "Shabaka " 
(Fig. 6): Kushite Kings wear various Crowns with double uraeus on the forehead.

(Fig. 7): Details of Ti's Crown from the Monumental Statue of Queen" Ti".

(Fig. 8): Head of King "Taharqa”.

(Fig. 9): The Royal Kushite Crown of God "Anhur-Shu".

(Fig. 10): Temple Relief of King "Tantamani" with gods "Amun" and "Mut".

(Fig. 11): The Ram's head amulet.

(Fig. 12): Kushite Kings wear various models of The Ram's head amulet.

(Fig. 13): The bracelet of the arm and wrist in the Bronze Statue of King "Shabaka".

(Fig. 14): The Head of King "Shebitku".

(Fig. 15): Reliefs of King "Shabaka " on "Isna" Naos.

(Fig. 16a): Statuette of unknown Kushite pharaoh.

(Fig. 16b): Statuette of Taharqa.

(Fig. 17): Statue of unknown Kushite King.

\section{Bibliography}

Abou-Bakre, A. J., Untersuchungen über die ägyptischen Kronen, (New York 1907).

Broekman, G., Hitchhiker's Guide to the Galaxy on Shabaka, GM 245, (2015).

Emberling, G., Nubia: Ancient Kingdoms of Africa. New York: Institute for the Study of the Ancient World, (2011), pp. 9-11.

Bianchi, R., S., Daily Life of the Nubians, (London 2004).

Fazzini, R. A., and others, Ancient Egyptian Art in the Brooklyn Museum, (New York 1989).

Gerard, P., F., The order of succession between Shabaka and Shabataka; A different view on the chronology of the Twentyfifth Dynasty, GM 245, (2015). 
Gozzoli, R., B., The Writing of History in Ancient Egypt during the First Millennium BC (1070 - 180 BC), (London 2006).

Leclant, J., Recherches sur les monuments Thébains de la XXVe dynastie égyptienne dite éthiopienne, Vol. 2, IFAO, Le Caire, (1965).

Macadam, M., F., L., The Temples of Kawa, Vol. I, Text, (London 1949).

Mûller, H. W., Ein Konigsbildnis der 26. Dynastie mit der ,Blauen Krone" im Museo Civico zu Bologna, ZÄS 80 (1955).

Mysliwiec, K., Royal Portraiture of the Dynasties XXI- XXX, (Mainz 1988).

River, C., The Kingdom of Kush: The History and Legacy of the Ancient Nubian Empire, (2017), p. 31ff.

Russmann, E. R., Two Royal Heads of the Late Period in Brooklyn, BMA X (1968-69).

Russmann, E. R., Further Aspects, (1969-70).

Russmann, E. R., The Representation of the King in the XXVth Dynasty, (1974).

Schäfer, H. Von., Eine Bronzefigure des Taharka, ZÄS 33 (1895).

Török, L., The Kingdom of Kush: Handbook of the Napatan-Meroitic Civilization, (1998).

Török, L., The Royal Crowns of Kush: a study in Middle Nile Valley regalia and iconography in the 1st millennia B.C. and A.D., (Oxford 1987).

Welsby, D., The Kingdom of Kush. (London 1996).

\section{References}

(i) Török, L., The Kingdom of Kush: Handbook of the NapatanMeroitic Civilization. (1998), p. 132.

(ii) Bianchi, R., S., Daily Life of the Nubians, (London 2004), p. 155.

(iii) Gerard P. F. Broekman, P., F., The order of succession between Shabaka and Shabataka; A different view on the chronology of the Twenty-fifth Dynasty, GM 245 (2015), PP. 17-31. 
(iv ) River, C., The Kingdom of Kush: The History and Legacy of the Ancient Nubian Empire, ( 2017), p. 31ff.

(v ) Broekman, G., Hitchhiker's Guide to the Galaxy on Shabaka, GM 245, (2015), p. 24.

(vi) Kitchen, K., A., The Third Intermediate Period in Egypt (1100650 BC), (1996), pp. 98f.

(vii) Emberling, G., Nubia: Ancient Kingdoms of Africa. New York: Institute for the Study of the Ancient World, (2011), pp. 9-11.

(viii) Russmann, E., Two Royal Heads of the Late Period in Brooklyn, BMA X (1968-69), p. 88.

(ix) More about Egyptian crowns, see: Abou-Bakre, A. J., Untersuchungen über die ägyptischen Kronen, (New York 1907), pp. $7 \mathrm{ff}$.

(x) Mûller, H. W., Ein Konigsbildnis der 26. Dynastie mit der ,Blauen Krone" im Museo Civico zu Bologna, ZÄS 80 (1955), p. 53.

(xi) Russmann, E. R. (1974), The Representation of the King in the XXVth Dynasty, pp. $27 \mathrm{f}$.

(xii) Török, L., The royal crowns of Kush : a study in Middle Nile Valley regalia and iconography in the 1st millennia B.C. and A.D., (Oxford 1987), p.4.

(xiii) Schäfer, H. Von., Eine Bronzefigure des Taharka, ZÄS 33 (1895), p. 115.

(xiv) This stela is considered a replica of Ancient Egyptian models and reflects in particular the memphite art of the Old Kingdom era, which was developed by the Libyan rulers in the north and later adopted by the Kushites, and therefore it is a very important pivotal centre for the Ancient style between the era of both the Libyans and the Kushites, as it is a living example of mixed art in this intermediate period, for more see: Fazzini, R. A., and others, Ancient Egyptian Art in the Brooklyn Museum, (New York 1989), no. 69.

(xv) Russmann, E. R., Representation, p. 32.

(xvi) Mysliwiec, K., Royal Portraiture of the Dynasties XXI- XXX, (Mainz 1988), p. 38. 
(xvii ) Török, L., The royal crowns of Kush, p. 14.

(xviii ) Russmann, E. R., Representation, p. 40.

(xix ) Leclant, J., Recherches sur les monuments Thébains de la XXVe dynastie égyptienne dite éthiopienne, vol. 2, IFAO, Le Caire, (1965), p. 38.

(xx ) Russmann, E. R., Representation, p. 41.

(xxi ) Török, L., The royal crowns of Kush, nos. 78, 80.

(xxii ) Macadam, M., F., L., The Temples of Kawa, Vol. I, Text, (London 1949), pls. X-b, XI-a, XVII-e, XXII a-b.

(xxiii ) Russmann, E. R., Representation, p. 25, n. 7.

(xxiv ) Morkot, R., G., The Black Pharaohs, Egypt's Nubian Rulers, (2000), pp. 52f.

(xxv ) Russmann, E. R., Two Royal Heads, (1968-69), p. 89.

(xxvi) Welsby, D., The Kingdom of Kush. (London 1996). p. 169. 